\title{
Ranibizumab for the treatment of degenerative ocular conditions
}

This article was published in the following Dove Press journal:

Clinical Ophthalmology

24 June 2014

Number of times this article has been viewed

\author{
Magdalini Triantafylla' \\ Horace F Massa ${ }^{2}$ \\ Doukas Dardabounis' \\ Zisis Gatzioufas ${ }^{2}$ \\ Vassilios Kozobolis' \\ Konstantinos loannakis' \\ Irfan Perente 1,3 \\ Georgios D Panos ${ }^{1,2}$ \\ 'Department of Ophthalmology, \\ University General Hospital of \\ Alexandroupolis, School of Medicine, \\ University of Thrace, Alexandroupolis, \\ Greece; ${ }^{2}$ Department of \\ Ophthalmology, Geneva University \\ Hospitals, Faculty of Medicine, \\ University of Geneva, Switzerland; \\ ${ }^{3}$ Beyoglou Eye Research and Teaching \\ Hospital, Istanbul University, Istanbul, \\ Turkey
}

Correspondence: Georgios D Panos Department of Ophthalmology, Geneva University Hospitals, HUG, Rue

Alcide - Jentzer 22, CH I2II Geneva I4, Switzerland

Tel +4l 795534739

Fax +4I 223828382

Email gdpanos@gmail.com

\begin{abstract}
Degenerative ocular conditions, such as age-related macular degeneration, diabetic retinopathy, retinal vein occlusions, and myopic degeneration, have become a major public health problem and a leading cause of blindness in developed countries. Anti-vascular endothelial growth factor (VEGF) drugs seem to be an effective and safe treatment for these conditions. Ranibizumab, a humanized monoclonal antibody antigen-binding fragment, which inhibits all biologically active isoforms of VEGF-A, is still the gold standard treatment for the majority of these pathological entities. In this review, we present the results of the most important clinical trials concerning the efficacy and safety of ranibizumab for the treatment of degenerative ocular conditions.
\end{abstract}

Keywords: age-related macular degeneration, diabetic macular edema, retinal vein occlusion, anti-VEGF, safety, efficacy, quality of life

\section{Introduction to degenerative ocular conditions and their management Age-related macular degeneration}

The disease was first described by Holloway and Verhoeff in 1929 and has grown to be an important public health problem ever since, with various resources trying to demonstrate the mechanisms being evolved. ${ }^{1-3}$ As the population ages, the percentage of patients suffering from age-related macular degeneration (AMD) increases rapidly, new therapeutic options are constantly under development, and research focuses on understanding the mechanisms related to the disease and the role of human genetics and environmental risk factors. ${ }^{4}$

AMD is a multifactorial disease characterized by progressive degeneration of photoreceptors and the retinal pigment epithelium (RPE) in the macular region of the retina, resulting in irreversible central vision loss. It is the leading cause of irreversible vision loss in individuals over 65 years in developed countries. ${ }^{5}$ In the US alone, over 10 million individuals have AMD, regardless of type. These numbers are projected to increase by $50 \%$ over the next 10 years. $^{6}$

AMD is classified into two types: non-neovascular (dry AMD) and neovascular (wet AMD), with the neovascular form of AMD responsible for the most severe and rapid visual loss, although it is less common, affecting only $10 \%$ of AMD patients; it is characterized by choroidal neovascularization (CNV) development. CNV consists of immature new pathological blood vessels growing from the choroid towards the retina, which can leak or exude fluid, causing damage to the retinal layers by separating its structures and resulting in loss of vision. Finally, this disturbance in the architecture of the eye - especially in the fovea - results in scarring, causing permanent loss of vision. 
AMD is influenced by genetics as well as environmental factors, such as diet and smoking, which are the most consistent non-genetic risk factors. ${ }^{7,8}$ Furthermore, hypertension and hyperlipidemia have been associated with AMD as well, and contribute in up to $75 \%$ of AMD cases. ${ }^{9-11}$ Vascular endothelial growth factor-A (VEGF-A) plays a critical role in the pathogenesis of neovascular AMD through its effects on angiogenesis and vascular permeability. Elevated levels of VEGF-A have been found in CNV membranes from patients with AMD. ${ }^{12,13}$ Ranibizumab targets all VEGF-A isoforms. Thus, this neovascular AMD treatment demonstrates stabilization and even improvement in vision for many patients.

\section{Polypoidal choroidal vasculopathy}

Polypoidal choroidal vasculopathy (PCV) was first identified as a distinct form of wet AMD in 1990 by Yannuzzi et $\mathrm{al}^{14}$ who reported a series of patients with polypoidal, subretinal vascular lesions that cause serous and/or hemorrhagic detachment of the RPE and exudative macular degeneration. Thus, it was described to be an abnormality of the choroidal vasculature and now represents a separate type of CNV. ${ }^{15-18}$

Several studies have suggested that genetic and environmental factors are associated with the clinical features of PCV, and systemic and ocular risk factors have been reported, such as systemic hypertension, ${ }^{19,20}$ elevated C-reactive protein (CRP) levels, smoking, central serous chorioretinopathy, ${ }^{21,22}$ RPE rips and tears, and pigment epithelial detachment (PED). ${ }^{23}$

Photodynamic treatment (PDT) with verteporfin is one of the most widely described treatment modalities for PCV in the literature. The intravitreal (IVT) injection of anti-VEGF agents against PCV and its outcomes is still questionable because studies have reported that PCV lesions were not resolved by anti-VEGF monotherapy. ${ }^{24,25}$ On the other hand, there are recent studies that contradict these findings by pointing out the disappearance of the polypoidal lesions and regression of the branching vascular network after anti-VEGF monotherapy, ${ }^{26}$ mostly because of its improved penetration due to its small molecular size. Treatment with ranibizumab appears to significantly decrease bleeding and exudation in $\mathrm{PCV} .{ }^{27}$

\section{Myopic degeneration}

Although myopia is a common visual disorder in the world, pathologic myopia is characterized by progressive anteroposterior elongation of the sclera and is associated with several complications. ${ }^{28}$ Its prevalence is $25 \%$ in the US and Western
Europe and higher (40\%-70\%) in Asians. ${ }^{29,30}$ Myopic eyes with very long axial lengths ( $\geq 26 \mathrm{~mm}$ ) or a high degree of myopic refractive error ( $\geq-6$ diopters) are classified as high myopia. ${ }^{31}$

In highly myopic eyes, choroidal atrophy and neovascularization are the most vision-threatening complications. ${ }^{32}$ Myopia is responsible for $62 \%$ of $\mathrm{CNV}$ cases in patients younger than 50 years with unfavorable prognosis. ${ }^{28}$ Visual acuity (VA) at 5 years after the onset of CNV decreases to $\leq 20 / 200$ in $89 \%$ of eyes and in $96 \%$ of eyes after 10 years. ${ }^{33}$ It is difficult to prevent the development of myopia and $\mathrm{CNV}$, so preserving VA represents the most important factor for myopic patients.

Anti-VEGF therapy has been used for the treatment of myopic CNV since 2005 and has shown good outcomes. ${ }^{34,35}$ VA improves in many cases and smaller CNV size contributes to good prognosis. ${ }^{36} \mathrm{CNV}$ due to myopia has been shown to respond faster to ranibizumab treatment compared to CNV due to neovascular AMD and fewer injections are necessary to reach stabilization of VA. ${ }^{37}$

\section{Diabetic macular edema}

Diabetes is a chronic condition characterized by elevated levels of glucose, and increases the risk of cardiovascular diseases, kidney failure, and nerve damage leading to serious complications. ${ }^{38}$ Ocular complications include Diabetic macular edema (DME), which is the main reason for deteriorated VA in industrialized countries. Nowadays, blindness from DME is preventable with detection and appropriate therapy. Treatment includes control of glycemia, arterial hypertension, and renal status.

DME is considered to be a result of breakdown of the vascular inner blood-retinal barrier (BRB), and occurs in one of two ways: 1) focal leakage from microaneurysms and 2) diffuse leakage from the walls of capillaries. ${ }^{39}$

The exact mechanism by which diabetes leads to DME is not known, but it is indicated that high glucose levels over time correlate with the onset and progression of diabetic retinopathy. ${ }^{40}$ Research has identified that VEGF expression plays a key role in its development.

Laser treatment has been an established strategy of treatment for DME for several years, and reduces the vision loss. ${ }^{40}$ Treatment for clinically significant (diabetic) macular edema (ME) has been focal/grid laser photocoagulation based on the Early Treatment Diabetic Retinopathy Study (ETDRS). ${ }^{41}$ Laser is applied to leaking microaneurysms and a grid pattern of larger burns at the level of the RPE is used to treat leakage. The destruction of the RPE induces apoptosis 
of retinal cells. ${ }^{42}$ In the macular area, secondary effects, such as enlargement of atrophic spots, affect VA.

Ranibizumab is the only anti-VEGF drug that has been approved by the US Food and Drug Administration (FDA) for the treatment of DME. Ranibizumab therapy represents an effective therapeutic agent for the treatment of DME and appears to improve retinal function, while recent trials have demonstrated that IVT injections can significantly induce resolution of edema and improve the VA of patients with DME. ${ }^{43-45}$

\section{Retinal vein occlusion}

Retinal vein occlusion (RVO) is the second most commonly occurring retinal vascular abnormality after diabetic retinopathy and is a significant cause of vision loss. The pathogenesis includes occlusion of veins by vascular clot, external compression, or damage to the vessel wall. ${ }^{46,47}$ Occlusion can occur either in the central retinal vein (central RVO [CRVO]) or branches of the retinal veins (branch RVO [BRVO]) and prognosis varies depending on which is occluded. ${ }^{48}$ VEGF plays an important role in the pathogenesis of ME in both CRVO and BRVO as they both lead to fluid leakage from capillaries, caused by the secretion of VEGF, and result in edema. ${ }^{49}$

The clinical presentation of patients with BRVO is less severe than that seen in patients with CRVO, because venous return is compromised in approximately less than half of the retina, rather than the entire retina. The major cause of visual loss in patients with RVO is ME, and nonperfusion of perifoveal capillaries also contributes to this. ${ }^{50}$ To date, grid or focal laser photocoagulation have been shown to reduce the visual loss and even improve VA; however, there have been limitations to this treatment. ${ }^{51}$

Recently, anti-inflammatory and anti-angiogenic therapeutic strategies have been used to target vascular permeability and leakage to reduce $\mathrm{ME}$ and improve vision. ${ }^{50,52}$ Corticosteroids (triamcinolone acetonide and dexamethasone) have shown potential to reduce edema in RVO. ${ }^{53,54}$ However, their side effects, such as cataract progression and elevation of intraocular pressure (IOP) have limited their use.

Consequently, treatment with anti-VEGF has been used successfully to treat ME and as elevated intraocular levels of VEGF have been demonstrated in patients with RVOs, anti-VEGF agents have been strongly suggested to be beneficial. ${ }^{55,56}$

\section{Retinitis pigmentosa}

Retinitis pigmentosa (RP) is an inherited degenerative rodcone retinal dystrophy caused by loss of photoreceptors, with a prevalence of $1 / 5,000 .{ }^{57,58}$ The basic symptom is night blindness, and in the long-run, patients suffer from progressive loss in the peripheral visual field. Finally, all these clinical symptoms result in blindness after several decades. ${ }^{57}$

Clinical examination of RP patients reveals cell loss with consecutive retinal thinning, but there are cases where ME exists and is associated with RPE abnormalities, which derange the $\mathrm{BRB}$, resulting in further reduction of $\mathrm{VA}$ in patients. ${ }^{57,59}$ In addition to RPE changes, it is possible that attenuation of choroidal blood flow may result in the development of PCV. ${ }^{60-62}$

A prevalence of $11 \%-20 \%$ of cystoid ME (CME) in RP patients has been reported using fluorescein angiography (FA) and fundus exam. ${ }^{63}$

Various treatments including topical and systemic carbonic anhydrase inhibitors, systemic corticosteroids, grid laser photocoagulation, and IVT triamcinolone acetonide (IVTA) have been used for the management of CME in RP patients, but have proven to be rather ineffective and include several complications. ${ }^{57,59,63,64}$

In a study where IVT ranibizumab was used as monotherapy, although significant reduction in foveal thickness and resolution of edema was noted in RP patients, no improvement of VA was established. ${ }^{65}$

\section{Overview of pharmacology of ranibizumab}

Angiogenesis consists of a series of biochemical and cellular processes that requires receptor activation by growth factors. ${ }^{66,67}$ Physiologic angiogenesis is necessary for human growth, maintenance, and repair; however when tissue hypoxia or inflammation occurs, pathologic angiogenesis enables tumor growth and causes tissue destruction. This is the reason why pathologic neovascularization and hyperpermeability in other organs, such as the eye, cause blindness from retinal detachment, uncontrollable glaucoma, and untreatable retinal edema.

The possibility that an inducible angiogenesis factor could be targeted to reduce tumor growth was first reported by Folkman in $1971 .^{68}$ By 1983 , vascular permeability factor was discovered, and after DNA sequencing and recognition of its role in angiogenesis, it was named VEGF. ${ }^{69}$ Therefore, various lines of investigation have identified VEGF as a critical molecule in angiogenesis. ${ }^{70}$

Angiogenesis is the hallmark of neovascular AMD (wet AMD), the leading cause of blindness in the elderly population. It has been indicated that VEGF-A is a major mediator of angiogenesis and vascular leakage in wet AMD. 
Several isoforms of VEGF-A can be generated due to alternative mRNA splicing. ${ }^{71}$

Six forms of VEGF have been identified so far, produced by alternative splicing $\left(\mathrm{VEGF}_{121}, \mathrm{VEGF}_{145}, \mathrm{VEGF}_{165}\right.$, $\mathrm{VEGF}_{183}, \mathrm{VEGF}_{189}$, and $\left.\mathrm{VEGF}_{206}\right) .{ }^{71}$ The role that each form plays remains unclear, but retinal expression of $\mathrm{VEGF}_{121}$ and VEGF $_{165}$ has been documented in normal eyes of rats, monkeys, and humans. ${ }^{72-75}$ VEGF is the key mediator in the development of choroidal neovascularization. Several VEGF inhibitors have been clinically developed. Among these, ranibizumab is a high-affinity recombinant antigen-binding fragment (Fab) that blocks all isoforms of VEGF-A.

Ranibizumab (Lucentis ${ }^{\circledR}$, Genentech, Inc., South San Francisco, CA, USA) is a humanized monoclonal antibody Fab engineered to bind with high affinity and to inhibit all biologically active isoforms of VEGF-A, so long as to block vessel permeability and angiogenesis. ${ }^{71}$ Ranibizumab was developed for intraocular administration as part of an antiVEGF program in AMD. ${ }^{76}$ It has also been shown to penetrate all layers of the rabbit retina. ${ }^{77}$ Its small molecule size ( $\left.48 \mathrm{kDa}\right)$ seems to be the cause of this ability, because a full-length antibody (trastuzumab, $148 \mathrm{kDa}$ ) was not able to penetrate all the retinal layers in monkeys. ${ }^{77}$ Microautoradiography analysis indicated that ranibizumab penetrated all retinal layers, reaching the choriocapillaris. ${ }^{77}$

Fabs have a shorter half-life than full-length antibodies and do not possess the fragment crystallizable $(\mathrm{Fc})$ domain, which has the ability to induce immune system activation; thus, a Fab would prevent Fc-dependent activation and narrow systemic antibody exposure. ${ }^{71}$ Ranibizumab was specifically designed not to promote inflammation because it lacks the Fc region.

IVT administration of ranibizumab on a monthly or per needed basis contributes to the preservation and improvement of VA; resolution of ME, as measured by retinal thickness; and low rates of serious ocular or systemic adverse events (AEs). ${ }^{55,56,78-81}$ IVT injection was selected to maximize the VEGF inhibitory effect in the retina, while limiting systemic VEGF inhibition. Thus, it minimizes interference with the normal extraocular roles of VEGF. ${ }^{77}$

The US FDA has approved ranibizumab for the treatment of neovascular (wet) AMD (initial approval: 2006), ME following RVO, and recently for treating DME. ${ }^{82-84}$

In monkeys and rabbits, the concentration of ranibizumab in the ocular compartment (vitreous, retina, and aqueous humor) decays by $50 \%$ approximately every 3 days. ${ }^{85-87}$ Radioactivity from labeled ranibizumab molecules has been detected in all retinal layers, at 24-hour
post-ITV injection. The distribution of ranibizumab into the retina and the aqueous humor following the injection implies that it reaches the systemic circulation by either entering the choroid vessels or via the aqueous humor outflow. ${ }^{85-87}$

Following IVT administration, ranibizumab predominantly localizes to the injected eye, with very little reaching the fellow eye or systemic circulation. According to the manufacturer, serum ranibizumab concentrations are approximately 90,000-fold lower than vitreal concentrations, and well below that which is required to systemically inhibit $50 \%$ of the biological activity of VEGF, with a predicted serum concentration of $0.22 \mathrm{ng} / \mathrm{mL}$ when administered monthly. ${ }^{85}$ Systemic exposure has been measured in less than $0.01 \%$ of vitreous exposure. ${ }^{85}$ In monkeys, the serum elimination half-life $\left(\mathrm{t}_{1 / 2}\right)$ of ranibizumab $(0.5 \mathrm{mg})$ after IVT administration was 3.59 days, while it has a terminal half-life of 2.9 days in the ocular compartments..$^{85}$ Extensive study of ranibizumab pharmacokinetics in the human eye is lacking and the pharmacokinetic information provided by the manufacturer is based on predictions from animal models and studies of human serum following IVT administration. ${ }^{88,89}$

\section{Long-term efficacy}

Anti-VEGF drugs have become of utmost importance in the treatment of macular degenerative diseases. Consistent data regarding long-term efficacy (at least 2 years) are available for the treatment of the wet form of AMD with ranibizumab. The recent introduction of aflibercept in the treatment of wet AMD promises results with fewer injections. ${ }^{90}$

Current research is focusing more on administration protocols to get the best long-term visual outcome and also potential new indications and on how to manage tachyphylaxis. ${ }^{91}$

\section{Wet AMD}

Pegaptanib, assessed in the VISION study (590 patients, multicenter, randomized, placebo-controlled trial), was the first drug showing long-term efficacy in the treatment of wet AMD with a loss higher than 15 letters of VA at 54 weeks varying from $45 \%$ in the treated group versus $59 \%$ in the control group. ${ }^{6}$

Ranibizumab was a revolution in long-term prognosis. It was the first drug that permitted a vision gain of 15 letters after 2 years in $26 \%$ and $33 \%$ of eyes treated respectively with 0.3 and $0.5 \mathrm{mg}$ versus $4 \%$ in the control group (MARINA study; 716 patients, randomized, placebo-controlled, doubleblind trial). ${ }^{80}$ 
Finally, the long-term superiority of ranibizumab over verteporfin was proved in the same month with the ANCHOR study (423 patients, randomized, double-blind trial). ${ }^{78}$ At 1-year follow-up, vision gain of 15 letters was found in 36\% and $40 \%$ of eyes treated respectively with 0.3 and $0.5 \mathrm{mg}$ versus $6 \%$ in the verteporfin group. ${ }^{78}$

Long-term efficacy improved from less vision loss to stabilization, and finally to vision gain thanks to the development of anti-VEGF drugs. Nowadays, research is focused on efficiency by adapting administration protocol. First of all, treatment should not be delayed, as latency between diagnosis and effective treatment is associated with poorer outcome at 12 months. Therefore, treatment should be carried out without delay. ${ }^{92,93}$

Reducing the amount of injection without inducing visual loss is the actual challenge. The loading dose during the first 3 months is the actual gold standard; Menghini et al could not show a benefit in VA at 2 years for patients having or not having received the loading dose; nevertheless, patients in both groups had the same amount of injections after 2 years' follow-up..$^{94}$

Quarterly injections after a 3-month loading seemed to be less effective at 2 years than monthly dosing (PIER study, randomized, double-blind with crossover trial) when compared to the MARINA or ANCHOR studies..$^{93}$ The EXCITE study confirmed previous results, but with only a 1-year follow-up. ${ }^{95}$

The HORIZON study included patients from the MARINA, ANCHOR, and FOCUS studies, treatment was administered at the investigator's discretion, and follow-up was until 60 months. Roughly, initial VA gain returned to baseline in the initial treated group whereas visual acuity decline was lowered in the group treated with a 24-month delay, a difference of -16.1 letters (EDTRS) compared to the initially treated group was observed ${ }^{96}$ Interestingly, $74 \%$ of patients from the treated group had VA loss after switching from a monthly injection to an investigator discretion administration protocol..$^{96}$ This might be due to lack of injection (mean number of injections after the initial 2 years of monthly injections: $4.4 \pm 5.3$ [standard deviation]), but could also be due to the progression of the AMD disease itself. ${ }^{96}$

Injection protocol based only on VA impairment (ie, loss of five letters on the ETDRS) was associated with a poor outcome at 24 months (best corrected VA [BCVA] decline by 4.3 letters from baseline) in the SECURE study. ${ }^{97}$ Therefore, actual treatment is based on a pro re nata (as needed) approach (VA, clinical examination, and imaging criteria) ${ }^{98}$ or treat and extend approach ${ }^{99}$ with a gradually extending interval of injections depending on fluid recurrence rate. Long-term data on alternative regimen administration protocol are encouraging with an improvement in VA and decrease to five injections per year based on in between protocol (pro re nata and extend) ${ }^{100}$ or only a small decline of VA after 2 years when compared with monthly injections. ${ }^{101}$

Recent literature also focuses on more cost-effective alternatives to ranibizumab. Bevacizumab and ranibizumab seem to have equivalent visual outcome at 1 (CATT trial) $)^{81}$ and 2 years ${ }^{101}$ but with a huge cost difference. Also, the sequential use of a loading dose of ranibizumab (nonselective VEGF inhibitors) followed by pegaptanib (selective VEGF inhibitor) as maintenance therapy shows good results at 1 year but needs further long-term assessment. ${ }^{102,103}$ This could be an alternative in patients with systemic comorbidities.

VA at 2 years after treatment of $\mathrm{PCV}$, a variant of wet AMD, was associated with a better outcome for patients in the ranibizumab group versus PDT group in a Japanese population. ${ }^{104}$

Long-term equivalence of aflibercept and ranibizumab was confirmed in the VIEW study (randomized, doubleblinded, controlled study). Administration protocol was $2 \mathrm{mg}$ aflibercept every 8 weeks after three monthly injections or $0.5 \mathrm{mg}$ ranibizumab every 4 weeks during the first year and then as needed. Results in BCVA at 96 weeks were similar but with five fewer injections in the aflibercept group. ${ }^{105}$

\section{CME in diabetic patients}

The RESOLVE trial (12-month, multicenter, shamcontrolled, double-masked study) reported improved VA (by 10.3 \pm 9.1 letters) in DME patients treated with ranibizumab, while reduction by $1.4 \pm 14.2$ letters was found in the sham group $(P<0.0001) .{ }^{43}$ Similarly, the mean central retinal thickness (CRT) reduction was $194.2 \pm 135.1 \mu \mathrm{m}$ with ranibizumab versus $48.4 \pm 153.4 \mu \mathrm{m}$ with sham $(P<0.0001){ }^{43}$ The RISE and RIDE trials demonstrated that a greater proportion of ranibizumab-treated patients had more than 15 letters gain in vision compared with placebo groups. ${ }^{106}$

The 3-year outcome from the READ-2 study (prospective, multicenter, randomized study) was in favor of prolonged ranibizumab treatment for DME. ${ }^{107}$ VA improved from 7.2 at 24 months to 10.3 ETDRS letters at 36 months. An important prognostic factor is baseline VA with a poor visual outcome at 2 years if the initial VA was at or lower than $20 / 125 .{ }^{108}$

\section{RVO}

In the RETAIN study (prospective follow-up of RVO trials' patients) $44 \%$ of patients with CRVO (treated with ranibizumab) had resolution of CME at 4-year follow-up 
and a visual recovery of more than $20 / 40$ in $64 \%$ of patients versus $28 \%$ in the unresolved group. ${ }^{109}$ Seventy percent of patients in the resolved CME group received their last injection within the first 2 years of treatment, whereas in the unresolved group, patients still needed frequent injections after 4 years. Therefore, unresolved CME in CRVO within the first 2 years is considered to be a bad prognostic factor. Seventy-six percent of BRVO patients had resolution of CME within 2 years, with a mean ETDRS VA of 74 letters at 48 months. Only 3.2 injections were necessary at year 4 in the unresolved group.

The GALILEO study (randomized, double-blind, multicenter study) assessed aflibercept efficacy to improve VA in CME secondary to CRVO in comparison to sham injection. ${ }^{110} \mathrm{VA}$ improved in $60 \%$ of the aflibercept group versus $30.4 \%$ in the sham group at 52 weeks. There are no long-term data available to date.

\section{Myopia}

Bevacizumab achieved complete closure in more than $90 \%$ of CNV in myopic patients at 2 years. ${ }^{111}$

Both bevacizumab and ranibizumab were effective in maintaining VA at 2 years, with only a slight decline when compared with 1-year results in myopic subfoveal CNV. The gain was 2.8 and 5.1 lines, respectively, in the bevacizumab and ranibizumab groups, with mean VA improvements from $20 / 145$ to $20 / 60$. No statistical difference was found between the two groups. ${ }^{12}$

A slight decline in VA after 2 years' follow-up was also confirmed by Yang et al probably due to the progression of macular myopic degeneration. Prognostic factors for a poor visual outcome were: baseline VA, recurrence, CNV size, and thickness of the choroid. ${ }^{113}$

Anti-VEGF treatment with ranibizumab also has promising results in complicated neovascular AMD with PED, ${ }^{114,115}$ CNV secondary to causes other than AMD, ${ }^{116}$ other inflammatory diseases, ${ }^{117,118}$ and retinopathy of prematurity. ${ }^{119}$ Efforts should be made to obtain more long-term data in these areas.

A summary of the most important clinical trials is depicted in Table 1.

\section{Safety and tolerability}

VEGF inhibitors, such as ranibizumab, play an important role in the management of retinal degenerative diseases. Their efficacy is unquestionable; however, the safety of IVT administration of ranibizumab is controversial as some evidence suggests that it may increase the risk of systemic side effects. ${ }^{120-123}$

\section{AMD}

Both the ANCHOR and MARINA studies showed that ranibizumab is safe and well-tolerated. ${ }^{79,80}$ There were no significant differences in ocular and non-ocular AEs between the ranibizumab groups and PDT or placebo controls. Ocular AEs included endophthalmitis, uveitis, vitreous hemorrhage, retinal detachment, retinal tear, or lens damage. Non-ocular (systemic) AEs included thromboembolic events (stroke, myocardial infarction), hypertension, and non-ocular hemorrhage.

The PIER study reported no ocular AEs such as endophthalmitis, uveitis, vitreous hemorrhage, rhegmatogenous retinal detachment, retinal tear, or lens damage. ${ }^{93,124}$ The rate of thromboembolic events was $0 \%$ in the ranibizumab group in the first year of the study, ${ }^{124}$ and $1.7 \%$ only for the $0.3 \mathrm{mg}$ group in the second year. ${ }^{93}$

The SUSTAIN study reported ocular AEs, including retinal hemorrhage, cataract, and RPE tear only in $1.2 \%$ of patients, while vitreous hemorrhage and thromboembolic events were observed in $3.7 \%$ of the patients. ${ }^{125}$

The SAILOR study reported ocular AEs including endophthalmitis and pseudoendophthalmitis in $<1 \%$ of patients. ${ }^{126}$ The study showed a slightly higher risk of stroke in the $0.5 \mathrm{mg}$ versus $0.3 \mathrm{mg}$ group (1.2\% versus $0.6 \%$, difference not significant). A previous history of stroke, arrhythmia, and congestive heart failure were found to be risk factors for stroke in the study.

Recently, the SECURE study showed that ranibizumab administered at the investigator's discretion as per the European Summary of Product Characteristics 2007 (SmPC, VA-guided flexible dosing regimen) was safe and welltolerated over 2 years. ${ }^{97}$ The most frequent ocular AEs were retinal hemorrhage (12.8\%), cataract (11.5\%), and increased IOP (6.4\%). The study also reported systemic AEs, such as hypertension ( $9 \%$ ), nasopharyngitis $(9 \%)$, and thromboembolic events (5.6\%). None of the deaths $(2.1 \%)$ that occurred during the study were related to the drug.

\section{CME in diabetic patients}

In the RESOLVE study (12-month, multicenter, shamcontrolled, double-masked study), ranibizumab was found to be safe with ocular and systemic AEs being comparable between the treatment and control groups.$^{43}$ Similarly, the READ-2 study reported no retinal toxic effects for up to 3 years. ${ }^{107}$ In the RISE and RIDE trials (randomized, multicenter, double-masked, 3-year trials, sham injectioncontrolled for 2 years), ranibizumab treatment was found to be safe, with a low incidence of serious AEs (19.7\% in the 
Table I Summary of the most important clinical ranibizumab trials

\begin{tabular}{|c|c|c|c|}
\hline Study & Design & $\begin{array}{l}\text { Number of } \\
\text { patients }\end{array}$ & Key results \\
\hline \multicolumn{4}{|l|}{ Wet AMD } \\
\hline $\mathrm{ANCHOR}^{78,79}$ & $\begin{array}{l}\text { Multicenter, randomized, double- } \\
\text { masked, active-treatment-controlled } \\
\text { clinical trial, 2-year }\end{array}$ & 423 & $\begin{array}{l}\text { I) } 94.3 \% \text { of patients given } 0.3 \mathrm{mg} \text { of ranibizumab and } 96.4 \% \text { of those } \\
\text { given } 0.5 \mathrm{mg} \text { lost }<\mathrm{I} 5 \text { letters, as compared with } 64.3 \% \text { of those in } \\
\text { the verteporfin group ( } P<0.00 \text { I for each comparison) } \\
\text { 2) VA improved by } \geq 15 \text { letters in } 35.7 \% \text { of the } 0.3 \mathrm{mg} \text { group } \\
\text { and } 40.3 \% \text { of the } 0.5 \mathrm{mg} \text { group, compared with } 5.6 \% \text { of the } \\
\text { verteporfin group }(P<0.00 \mathrm{I} \text { for each comparison) }\end{array}$ \\
\hline MARINA $^{80}$ & $\begin{array}{l}\text { Multicenter, 2-year, double-blind, } \\
\text { sham-controlled study }\end{array}$ & 716 & $\begin{array}{l}\text { VA improved by } \geq 15 \text { letters in } 24.8 \% \text { of the } 0.3 \mathrm{mg} \text { group and } 33.8 \% \\
\text { of the } 0.5 \mathrm{mg} \text { group, as compared with } 5.0 \% \text { of the sham-injection } \\
\text { group }(P<0.00 \text { I for both doses })\end{array}$ \\
\hline PIER $^{93,124}$ & $\begin{array}{l}\text { Phase Illb, multicenter, randomized, } \\
\text { double-masked, 2-year, sham } \\
\text { injection-controlled trial }\end{array}$ & 184 & $\begin{array}{l}\text { VA decreased an average of } 21.4,2.2 \text {, and } 2.3 \text { letters from baseline in } \\
\text { the sham, } 0.3 \mathrm{mg} \text {, and } 0.5 \mathrm{mg} \text { groups }(P<0.000 \text { I for each ranibizumab } \\
\text { group vs sham })\end{array}$ \\
\hline PrONTO ${ }^{136}$ & $\begin{array}{l}\text { 2-year prospective, uncontrolled, } \\
\text { variable-dosing regimen based on } \\
\text { OCT }\end{array}$ & $\begin{array}{l}40 \text { ( } 37 \text { completed } \\
\text { the study) }\end{array}$ & $\begin{array}{l}\text { Mean VA improved by II.I letters }(P<0.00 \mathrm{I}) \text { and the OCT-CRT } \\
\text { decreased by } 212 \mu \mathrm{m}(P<0.00 \mathrm{I}) \text {. These outcomes were achieved } \\
\text { with an average of } 9.9 \text { injections over } 24 \text { months }\end{array}$ \\
\hline \multicolumn{4}{|l|}{ RVO } \\
\hline BRAVO ${ }^{128}$ & $\begin{array}{l}\text { Multicenter, double-masked, } \\
\text { 6-month trial }\end{array}$ & 397 & $\begin{array}{l}\text { Patients treated with ranibizumab reported greater mean } \\
\text { improvements in visual function, with substantial differences observed } \\
\text { as early as month I compared with sham patients (all } P<0.05 \text { ) }\end{array}$ \\
\hline CRUISE ${ }^{128}$ & $\begin{array}{l}\text { Multicenter, double-masked, } \\
\text { 6-month trial }\end{array}$ & 392 & $\begin{array}{l}\text { Patients treated with ranibizumab reported greater mean } \\
\text { improvements in visual function, with substantial differences observed } \\
\text { as early as month I compared with sham patients (all } P<0.05 \text { ) }\end{array}$ \\
\hline RETAIN ${ }^{109}$ & $\begin{array}{l}\text { Prospective follow-up of a subset } \\
\text { of patients from two Phase III trials } \\
\text { (Genentech-sponsored ranibizumab } \\
\text { study RVO trials). Mean follow-up of } \\
49.0 \text { months for BRVO patients and } \\
49.7 \text { months for CRVO }\end{array}$ & 66 & $\begin{array}{l}\text { I) } 50 \% \text { of BRVO patients had edema resolution; } 80 \% \text { of BRVO } \\
\text { patients had a final VA } \geq 20 / 40 \\
\text { 2) } 44 \% \text { of CRVO patients had edema resolution; } 64.3 \% \text { of patients } \\
\text { with resolved ME vs } 27.8 \% \text { of patients with unresolved ME had a } \\
\text { final VA } \geq 20 / 40\end{array}$ \\
\hline \multicolumn{4}{|l|}{ DME } \\
\hline RESOLVE $^{43}$ & $\begin{array}{l}\text { I2-month, multicenter, sham- } \\
\text { controlled, double-masked study }\end{array}$ & 151 & $\begin{array}{l}\text { I) VA improved from baseline by } 10.3 \pm 9.1 \text { letters with ranibizumab } \\
\text { and declined by I. } 4 \pm 14.2 \text { letters with sham }(P<0.000 \mathrm{I}) \\
\text { 2) Mean } C R T \text { reduction was } 194.2 \pm 135.1 \mu \mathrm{m} \text { with ranibizumab and } \\
48.4 \pm I 53.4 \mu \mathrm{m} \text { with sham }(P<0.000 I)\end{array}$ \\
\hline RISE $^{106}$ & $\begin{array}{l}\text { Phase III, randomized, multicenter, } \\
\text { double-masked, 3-year trials, sham } \\
\text { injection-controlled for } 2 \text { years }\end{array}$ & 377 & $\begin{array}{l}\text { Greater proportion of ranibizumab-treated patients had } \geq 15 \text { letters } \\
\text { gain in vision compared with placebo group, with } 5 \mathrm{I} .2 \% \text { for the } 0.3 \mathrm{mg} \\
\text { ranibizumab group, } 41.6 \% \text { for the } 0.5 \mathrm{mg} \text { ranibizumab group, vs } 22.0 \% \\
\text { for the placebo groups }(P<0.000 \mathrm{I})\end{array}$ \\
\hline $\mathrm{RIDE}^{106}$ & $\begin{array}{l}\text { Phase III, randomized, multicenter, } \\
\text { double-masked, 3-year trials, sham } \\
\text { injection-controlled for } 2 \text { years }\end{array}$ & 382 & $\begin{array}{l}\text { Greater proportion of ranibizumab-treated patients had } \geq 15 \text { letters } \\
\text { gain in vision compared with placebo group, with } 36.8 \% \text { for the } 0.3 \mathrm{mg} \\
\text { ranibizumab group, } 40.2 \% \text { for the } 0.5 \mathrm{mg} \text { ranibizumab group, vs } 19.2 \% \\
\text { for the placebo groups }(P<0.000 \mathrm{I})\end{array}$ \\
\hline
\end{tabular}

Abbreviations: AMD, age-related macular degeneration; BRVO, branch retinal vein occlusion; CRT, central retinal thickness; CRVO, central retinal vein occlusion; DME, diabetic macular edema; ME, macular edema; OCT, optical coherence tomography; RVO, retinal vein occlusion; VA, visual acuity; vs, versus.

$0.5 \mathrm{mg}$ group and $19.8 \%$ in the $0.3 \mathrm{mg}$ group), and without significant increase in the incidence of deaths. ${ }^{106}$ Recently, the RESTORE extension study (Phase IIIb, multicenter, 12-month, randomized core study and 24-month open-label extension study) reported no cases of endophthalmitis, retinal tear, or retinal detachment. ${ }^{127}$ The most frequent ocular and non-ocular AEs over 3 years were cataract (16.3\%) and nasopharyngitis $(23.3 \%)$, respectively. ${ }^{127}$ There were no deaths related to the drug.

\section{RVO}

The BRAVO and CRUISE trials reported increased IOP (5.4\% and $8.5 \%$, respectively) in patients receiving $0.5 \mathrm{mg}$ ranibizumab; low incidence of cataract $(<4 \%$ in both studies); no retinal detachment; and only one case of endophthalmitis (in the BRAVO study, $0.5 \mathrm{mg}$ ranibizumab group). ${ }^{128}$ Recently, the RETAIN study reported four severe ocular AEs (retinal tear, vitreous hemorrhage, severe reaction to povidone-iodine, and superior hemi-RVO) that were 
not related to ranibizumab. ${ }^{109}$ Thirteen patients experienced severe systemic AEs, such as tachycardia, chest discomfort, syncope, and arrhythmia; none of these were attributable to the drug.

For the time being, there are no long-term data on the safety of ranibizumab treatment for myopic CNV, inflammatory $\mathrm{CNV}$, and retinopathy of prematurity (ROP). A recent study by Castellanos et al (six patients, 3 years' follow-up), reported complete resolution of neovascularization in patients with ROP after a single injection, with no AEs. ${ }^{119}$ Further larger and longer studies are needed to address the long-term safety and efficacy for these conditions.

\section{Patient-reported outcomes - quality of life}

In a recent study by Finger et al (multicenter, noninterventional study with 3,470 wet AMD patients, upload period: 3 months, final follow-up: 12 months), an improvement of subjective vision was reported by $46.3 \%$ of patients at first follow-up after upload and by $29.5 \%$ at the final followup. ${ }^{129}$ Patients' voice-related quality of life (National Eye Institute 25-item Visual Function Questionnaire [NEI-VFQ 25] summary score) showed positive stabilization with a mean change of 0.73 (standard error $=0.37, P=0.0501$ ) compared with baseline.

Frennesson et al observed improved quality of life for distance activities from $54 \pm 28$ points to $63 \pm 28$ points $(P<0.0001)$, but significantly $(P=0.024)$ more for near activities, from $49 \pm 26$ points to $63 \pm 26$ points $(P<0.0001)$. Reading newspaper text showed the highest increase of all in the quality of life score. ${ }^{130}$

On the other hand, a prospective single-center study by Rung and Lövestam-Adrian (50 patients with wet AMD treated with ranibizumab, with a loading dose of three monthly injections and decision on reinjection according to VA and optical coherence tomography findings, 3 years' follow-up), using the NEI-VFQ 25, reported no significant decrease in mental health $(P=0.529)$ or ability to read a newspaper $(P=0.21)$, but did report decreases in distance activities (reading street signs, steps, going to the theater) from $57 \pm 27$ points to $46 \pm 31$ points $(P=0.007) .{ }^{131}$

Finally, the HELIOS study (prospective, observational, multicenter, open-label study of $0.5 \mathrm{mg}$ of ranibizumab, follow-up of $24 \pm 3$ months) showed that at 6 months, improvements over baseline were significant for both NEI-VFQ $25(P=0.03)$ and the Health Utilities Index Mark 3 (HUI3; $P=0.02$ ), but not at 12 and 24 months, and that improvement was maintained at 24 months in 38\% (NEI-VFQ 25) and $34 \%$ (HUI3) of patients. ${ }^{132}$

\section{Conclusion}

Ranibizumab is an efficient and safe treatment for various degenerative ocular conditions, such as AMD, DME, and ME secondary to RVO. The LUMINOUS program (5-year prospective, multicenter, noninterventional study, with planned sample size of 30,000 subjects worldwide) is currently evaluating the long-term safety and efficacy of ranibizumab in addition to understanding its treatment patterns and outcomes for wet AMD and DME in the real-world clinical setting. ${ }^{133}$

Ranibizumab also seems to be efficient and safe for the treatment of other degenerative ocular conditions, such as myopic and inflammatory CNV and ROP. Recently, ranibizumab was found to be effective in the treatment of corneal neovascularization as well. ${ }^{134}$ Research should be focused on these topics.

Finally another anti-VEGF drug, VEGF-trap aflibercept (Eylea $^{\circledR}$, Regeneron, Tarrytown, NY, USA; Bayer AG, Leverkusen, Germany) has been recently approved for the treatment of wet AMD. The VIEW-1 and VIEW-2 trials showed that aflibercept is an effective treatment for wet AMD, promising to decrease the frequency of injections and subsequently reduce the risk from monthly IVT injections. ${ }^{135}$ Similarly, the GALILEO study showed significant functional and anatomic benefits after 1 year in patients with ME secondary to CRVO treated with aflibercept. ${ }^{110}$ However, ranibizumab still remains the gold standard treatment for the majority of degenerative ocular conditions. Future research results are anticipated with great interest.

\section{Disclosure}

The authors report no conflicts of interest in this work.

\section{References}

1. Apte RS, Scheufele TA, Blomquist PH. Etiology of blindness in an urban community hospital setting. Ophthalmology. 2001;108(4): 693-696.

2. Holloway TB, Verhoeff FH. Disc-like degeneration of the macula with microscopic report concerning a tumor-like mass in the macular region. Trans Am Ophthalmol Soc. 1928;26:206-228.

3. Ivandic BT, Ivandic T. Low-level laser therapy improves vision in patients with age-related macular degeneration. Photomed Laser Surg. 2008;26(3):241-245.

4. Do DV. Antiangiogenic approaches to age-related macular degeneration in the future. Ophthalmology. 2009;116(10 Suppl):S24-S26.

5. Joussen AM, Bornfeld N. The treatment of wet age-related macular degeneration. Dtsch Arztebl Int. 2009;106(18):312-317.

6. Gragoudas ES, Adamis AP, Cunningham ET Jr, Feinsod M, Guyer DR; VEGF Inhibition Study in Ocular Neovascularization Clinical Trial Group. Pegaptanib for neovascular age-related macular degeneration. N Engl J Med. 2004;351(27):2805-2816.

7. Chakravarthy U, Wong TY, Fletcher A, et al. Clinical risk factors for age-related macular degeneration: a systematic review and meta-analysis. BMC Ophthalmol. 2010;10:31. 
8. Clemons TE, Milton RC, Klein R, Seddon JM, Ferris FL 3rd; Age-Related Eye Disease Study Research Group. Risk factors for the incidence of Advanced Age-Related Macular Degeneration in the Age-Related Eye Disease Study (AREDS) AREDS report no. 19 Ophthalmology. 2005;112(4):533-539.

9. Edwards AO, Ritter R 3rd, Abel KJ, Manning A, Panhuysen C, Farrer LA. Complement factor $\mathrm{H}$ polymorphism and age-related macular degeneration. Science. 2005;308(5720):421-424.

10. Kabasawa S, Mori K, Horie-Inoue K, et al. Associations of cigarette smoking but not serum fatty acids with age-related macular degeneration in a Japanese population. Ophthalmology. 2011;118(6):1082-1088.

11. Munch IC, Linneberg A, Larsen M. Precursors of age-related macular degeneration: associations with physical activity, obesity, and serum lipids in the inter99 eye study. Invest Ophthalmol Vis Sci. 2013; 54(6):3932-3940.

12. Gold B, Merriam JE, Zernant J, et al. Variation in factor B (BF) and complement component 2 (C2) genes is associated with age-related macular degeneration. Nat Genet. 2006;38(4):458-462.

13. Rakic JM, Lambert V, Devy L, et al. Placental growth factor, a member of the VEGF family, contributes to the development of choroidal neovascularization. Invest Ophthalmol Vis Sci. 2003;44(7):3186-3193.

14. Yannuzzi LA, Sorenson J, Spaide RF, Lipson B. Idiopathic polypoidal choroidal vasculopathy (IPCV). Retina. 1990;10(1):1-8.

15. Kleiner RC, Brucker AJ, Johnston RL. The posterior uveal bleeding syndrome. Retina. 1990;10(1):9-17.

16. Stern RM, Zakov ZN, Zegarra H, Gutman FA. Multiple recurrent serosanguineous retinal pigment epithelial detachments in black women. Am J Ophthalmol. 1985;100(4):560-569.

17. Yannuzzi LA, Wong DW, Sforzolini BS, et al. Polypoidal choroidal vasculopathy and neovascularized age-related macular degeneration. Arch Ophthalmol. 1999;117(11):1503-1510.

18. Lafaut BA, Aisenbrey S, Van den Broecke C, Bartz-Schmidt KU, Heimann K. Polypoidal choroidal vasculopathy pattern in agerelated macular degeneration: a clinicopathologic correlation. Retina. 2000;20(6):650-654.

19. Sakurada Y, Yoneyama S, Imasawa M, Iijima H. Systemic risk factors associated with polypoidal choroidal vasculopathy and neovascular age-related macular degeneration. Retina. 2013;33(4):841-845.

20. Hirami Y, Tsujikawa A, Otani A, et al. Hemorrhagic complications after photodynamic therapy for polypoidal choroidal vasculopathy. Retina. 2007;27(3):335-341.

21. Kikuchi M, Nakamura M, Ishikawa K, et al. Elevated C-reactive protein levels in patients with polypoidal choroidal vasculopathy and patients with neovascular age-related macular degeneration. Ophthalmology. 2007;114(9):1722-1727.

22. Cackett P, Yeo I, Cheung CM, et al. Relationship of smoking and cardiovascular risk factors with polypoidal choroidal vasculopathy and age-related macular degeneration in Chinese persons. Ophthalmology. 2011;118(5):846-852.

23. Cackett P, Wong D, Yeo I. A classification system for polypoidal choroidal vasculopathy. Retina. 2009;29(2):187-191.

24. Tsujikawa A, Ooto S, Yamashiro K, Tamura H, Otani A, Yoshimura N. Treatment of polypoidal choroidal vasculopathy by intravitreal injection of bevacizumab. Jpn J Ophthalmol. 2010;54(4):310-319.

25. Stangos AN, Gandhi JS, Nair-Sahni J, Heimann H, Pournaras CJ, Harding SP. Polypoidal choroidal vasculopathy masquerading as neovascular age-related macular degeneration refractory to ranibizumab. Am J Ophthalmol. 2010;150(5):666-673.

26. Nakashizuka H, Mitsumata M, Okisaka S, et al. Clinicopathologic findings in polypoidal choroidal vasculopathy. Invest Ophthalmol Vis Sci. 2008;49(11):4729-4737.

27. Cho M, Barbazetto IA, Freund KB. Refractory neovascular age-related macular degeneration secondary to polypoidal choroidal vasculopathy. Am J Ophthalmol. 2009;148(1):70-78.e1.

28. Cohen SY, Laroche A, Leguen Y, Soubrane G, Coscas GJ. Etiology of choroidal neovascularization in young patients. Ophthalmology. 1996;103(8):1241-1244.
29. Saw SM. A synopsis of the prevalence rates and environmental risk factors for myopia. Clin Exp Optom. 2003;86(5):289-294.

30. Kempen JH, Mitchell P, Lee KE, et al. The prevalence of refractive errors among adults in the United States, Western Europe, and Australia. Arch Ophthalmol. 2004;122(4):495-505.

31. Jacobi FK, Zrenner E, Broghammer M, Pusch CM. A genetic perspective on myopia. Cell Mol Life Sci. 2005;62(7-8):800-808.

32. Hayashi K, Ohno-Matsui K, Shimada N, et al. Long-term pattern of progression of myopic maculopathy: a natural history study. Ophthalmology. 2010;117(8):1595-1611, 1611.e1-e4.

33. Yoshida T, Ohno-Matsui K, Yasuzumi K, et al. Myopic choroidal neovascularization: a 10-year follow-up. Ophthalmology. 2003;110(7): 1297-1305.

34. Nguyen QD, Shah S, Tatlipinar S, Do DV, Anden EV, Campochiaro PA. Bevacizumab suppresses choroidal neovascularisation caused by pathological myopia. Br J Ophthalmol. 2005;89(10):1368-1370.

35. Ikuno Y, Sayanagi K, Soga K, et al. Intravitreal bevacizumab for choroidal neovascularization attributable to pathological myopia: one-year results. Am J Ophthalmol. 2009;147(1):94-100.e1.

36. Nakanishi H, Tsujikawa A, Yodoi Y, et al. Prognostic factors for visual outcomes 2-years after intravitreal bevacizumab for myopic choroidal neovascularization. Eye (Lond). 2011;25(3):375-381.

37. Hefner L, Riese J, Gerding H. Three years follow-up results of ranibizumab treatment for choroidal neovascularization secondary to pathologic myopia. Klin Monbl Augenheilkd. 2013;230(4): 401-404.

38. Romero-Aroca P. Current status in diabetic macular edema treatments. World J Diabetes. 2013;4(5):165-169.

39. Bresnick GH. Diabetic macular edema. A review. Ophthalmology. 1986; 93(7):989-997.

40. The effect of intensive treatment of diabetes on the development and progression of long-term complications in insulin-dependent diabetes mellitus. The Diabetes Control and Complications Trial Research Group. N Engl J Med. 1993;329(14):977-986.

41. Photocoagulation for diabetic macular edema. Early Treatment Diabetic Retinopathy Study report number 1. Early Treatment Diabetic Retinopathy Study research group. Arch Ophthalmol. 1985; 103(12):1796-1806.

42. Brownlee M. Biochemistry and molecular cell biology of diabetic complications. Nature. 2001;414(6865):813-820.

43. Massin P, Bandello F, Garweg JG, et al. Safety and efficacy of ranibizumab in diabetic macular edema (RESOLVE Study): a 12-month, randomized, controlled, double-masked, multicenter phase II study. Diabetes Care. 2010;33(11):2399-2405.

44. Mitchell P, Bandello F, Schmidt-Erfurth U, et al; RESTORE study group. The RESTORE study: ranibizumab monotherapy or combined with laser versus laser monotherapy for diabetic macular edema. $\mathrm{Oph}$ thalmology. 2011;118(4):615-625.

45. Nguyen QD, Shah SM, Heier JS, et al; READ-2 Study Group. Primary end point (six months) results of the Ranibizumab for Edema of the mAcula in diabetes (READ-2) study. Ophthalmology. 2009;116(11):2175-2181.e1.

46. Parodi MB, Bandello F. Branch retinal vein occlusion: classification and treatment. Ophthalmologica. 2009;223(5):298-305.

47. Hayreh SS, Zimmerman MB, Podhajsky P. Incidence of various types of retinal vein occlusion and their recurrence and demographic characteristics. Am J Ophthalmol. 1994;117(4):429-441.

48. Wong TY, Scott IU. Clinical practice. Retinal-vein occlusion. N Engl J Med. 2010;363(22):2135-2144.

49. Macdonald D. The ABCs of RVO: a review of retinal venous occlusion. Clin Exp Optom. Epub 2013 Nov 20.

50. Argon laser photocoagulation for macular edema in branch vein occlusion. The Branch Vein Occlusion Study Group. Am J Ophthalmol. 1984;98(3):271-282.

51. Shilling JS, Jones CA. Retinal branch vein occlusion: a study of argon laser photocoagulation in the treatment of macular oedema. $\mathrm{Br} \mathrm{J} \mathrm{Oph-}$ thalmol. 1984;68(3):196-198. 
52. Natural history and clinical management of central retinal vein occlusion. The Central Vein Occlusion Study Group. Arch Ophthalmol. 1997;115(4):486-491.

53. Jonas JB, Kreissig I, Degenring RF. Intravitreal triamcinolone acetonide as treatment of macular edema in central retinal vein occlusion. Graefes Arch Clin Exp Ophthalmol. 2002;240(9):782-783.

54. Jain N, Stinnett SS, Jaffe GJ. Prospective study of a fluocinolone acetonide implant for chronic macular edema from central retinal vein occlusion: thirty-six-month results. Ophthalmology. 2012;119(1):132-137.

55. Brown DM, Campochiaro PA, Singh RP, et al; CRUISE Investigators. Ranibizumab for macular edema following central retinal vein occlusion: six-month primary end point results of a phase III study. Ophthalmology. 2010;117(6):1124-1133.e1.

56. Campochiaro PA, Heier JS, Feiner L, et al. Ranibizumab for macular edema following branch retinal vein occlusion: six-month primary end point results of a phase III study. Ophthalmology. 2010;117(6): 1102-1112.e1

57. Hamel C. Retinitis pigmentosa. Orphanet J Rare Dis. 2006;1:40

58. Adler R. Mechanisms of photoreceptor death in retinal degenerations. From the cell biology of the 1990s to the ophthalmology of the $21 \mathrm{st}$ century? Arch Ophthalmol. 1996;114(1):79-83.

59. Chong NH, Bird AC. Management of inherited outer retinal dystrophies: present and future. Br J Ophthalmol. 1999;83(1):120-122.

60. Mauget-Faÿsse M, Cornut PL, Quaranta El-Maftouhi M, Leys A. Polypoidal choroidal vasculopathy in tilted disk syndrome and high myopia with staphyloma. Am J Ophthalmol. 2006;142(6):970-975.

61. Langham ME, Kramer T. Decreased choroidal blood flow associated with retinitis pigmentosa. Eye (Lond). 1990;4(Pt 2):374-381.

62. Shintani K, Shechtman DL, Gurwood AS. Review and update: current treatment trends for patients with retinitis pigmentosa. Optometry. 2009;80(7):384-401.

63. Hajali M, Fishman GA, Anderson RJ. The prevalence of cystoid macular oedema in retinitis pigmentosa patients determined by optical coherence tomography. Br J Ophthalmol. 2008;92(8):1065-1068.

64. Grover S, Apushkin MA, Fishman GA. Topical dorzolamide for the treatment of cystoid macular edema in patients with retinitis pigmentosa. Am J Ophthalmol. 2006;141(5):850-858.

65. Salom D, Diaz-Llopis M, García-Delpech S, et al. Intravitreal ranibizumab in the treatment of cystoid macular edema associated with retinitis pigmentosa. J Ocul Pharmacol Ther. 2010;26(5):531-532.

66. Folkman J, Shing Y. Angiogenesis. J Biol Chem. 1992;267(16): 10931-10934.

67. Yancopoulos GD, Davis S, Gale NW, Rudge JS, Wiegand SJ, Holash J. Vascular-specific growth factors and blood vessel formation. Nature. 2000;407(6801):242-248

68. Folkman J. Tumor angiogenesis: therapeutic implications. $N$ Engl J Med. 1971;285(21):1182-1186.

69. Ferrara N, Henzel WJ. Pituitary follicular cells secrete a novel heparinbinding growth factor specific for vascular endothelial cells. Biochem Biophys Res Commun. 1989;161(2):851-858.

70. Ferrara N, Gerber HP, LeCouter J. The biology of VEGF and its receptors. Nat Med. 2003;9(6):669-676.

71. Ferrara N, Damico L, Shams N, Lowman H, Kim R. Development of ranibizumab, an anti-vascular endothelial growth factor antigen binding fragment, as therapy for neovascular age-related macular degeneration. Retina. 2006;26(8):859-870.

72. Xu L, Lu T, Tuomi L, et al. Pharmacokinetics of ranibizumab in patients with neovascular age-related macular degeneration: a population approach. Invest Ophthalmol Vis Sci. 2013;54(3):1616-1624.

73. Wagner JG. Pharmacokinetic absorption plots from oral data alone or oral/intravenous data and an exact Loo-Riegelman equation. J Pharm Sci. 1983;72(7):838-842.

74. Wagner JG, Nelson E. Kinetic analysis of blood levels and urinary excretion in the absorptive phase after single doses of drug. J Pharm Sci. 1964;53:1392-1403.

75. Lobo ED, Hansen RJ, Balthasar JP. Antibody pharmacokinetics and pharmacodynamics. J Pharm Sci. 2004;93(11):2645-2668.
76. Blick SK, Keating GM, Wagstaff AJ. Ranibizumab. Drugs. 2007;67(8):1199-1206; discussion 1207-1209.

77. Heier JS, Antoszyk AN, Pavan PR, et al. Ranibizumab for treatment of neovascular age-related macular degeneration: a phase I/II multicenter, controlled, multidose study. Ophthalmology. 2006;113(4):633. e631-e634.

78. Brown DM, Kaiser PK, Michels M, et al; ANCHOR Study Group. Ranibizumab versus verteporfin for neovascular age-related macular degeneration. $N$ Engl J Med. 2006;355(14):1432-1444

79. Brown DM, Michels M, Kaiser PK, Heier JS, Sy JP, Ianchulev T; ANCHOR Study Group. Ranibizumab versus verteporfin photodynamic therapy for neovascular age-related macular degeneration: two-year results of the ANCHOR study. Ophthalmology. 2009;116(1): 57-65.e5.

80. Rosenfeld PJ, Brown DM, Heier JS, et al. Ranibizumab for neovascular age-related macular degeneration. $N$ Engl J Med. 2006;355(14): 1419-1431.

81. Martin DF, Maguire MG, Ying GS, Grunwald JE, Fine SL, Jaffe GJ. Ranibizumab and bevacizumab for neovascular age-related macular degeneration. N Engl J Med. 2011;364(20):1897-1908.

82. Lloyd R, Harris J, Wadhwa S, Chambers W. Food and Drug Administration approval process for ophthalmic drugs in the US. Curr Opin Ophthalmol. 2008;19(3):190-194.

83. Krispel C, Rodrigues M, Xin X, Sodhi A. Ranibizumab in diabetic macular edema. World J Diabetes. 2013;4(6):310-318.

84. Belavic JM. Drug updates and approvals: 2012 in review. Nurse Pract. 2013;38(2):24-42; quiz 42-23.

85. Gaudreault J, Fei D, Beyer JC, et al. Pharmacokinetics and retinal distribution of ranibizumab, a humanized antibody fragment directed against VEGF-A, following intravitreal administration in rabbits. Retina. 2007;27(9):1260-1266.

86. Gaudreault J, Fei D, Rusit J, Suboc P, Shiu V. Preclinical pharmacokinetics of Ranibizumab (rhuFabV2) after a single intravitreal administration. Invest Ophthalmol Vis Sci. 2005;46(2):726-733.

87. Bakri SJ, Snyder MR, Reid JM, Pulido JS, Ezzat MK, Singh RJ. Pharmacokinetics of intravitreal ranibizumab (Lucentis). Ophthalmology. 2007;114(12):2179-2182

88. Chong V. Biological, preclinical and clinical characteristics of inhibitors of vascular endothelial growth factors. Ophthalmologica. 2012;227 Suppl 1:2-10.

89. Krohne TU, Liu Z, Holz FG, Meyer CH. Intraocular pharmacokinetics of ranibizumab following a single intravitreal injection in humans. $\mathrm{Am}$ J Ophthalmol. 2012;154(4):682-686.e2.

90. Stewart MW. Clinical and differential utility of VEGF inhibitors in wet age-related macular degeneration: focus on aflibercept. Clin Ophthalmol. 2012;6:1175-1186.

91. Forooghian F, Cukras C, Meyerle CB, Chew EY, Wong WT. Tachyphylaxis after intravitreal bevacizumab for exudative age-related macular degeneration. Retina. 2009;29(6):723-731.

92. Muether PS, Hoerster R, Hermann MM, Kirchhof B, Fauser S. Long-term effects of ranibizumab treatment delay in neovascular agerelated macular degeneration. Graefes Arch Clin Exp Ophthalmol. 2013;251(2):453-458.

93. Abraham P, Yue H, Wilson L. Randomized, double-masked, shamcontrolled trial of ranibizumab for neovascular age-related macular degeneration: PIER study year 2. Am J Ophthalmol. 2010;150(3):315-324.e1.

94. Menghini M, Kloeckener-Gruissem B, Fleischhauer J, et al. Impact of loading phase, initial response and CFH genotype on the long-term outcome of treatment for neovascular age-related macular degeneration. PLoS One. 2012;7(7):e42014.

95. Schmidt-Erfurth U, Eldem B, Guymer R, et al; EXCITE Study Group. Efficacy and safety of monthly versus quarterly ranibizumab treatment in neovascular age-related macular degeneration: the EXCITE study. Ophthalmology. 2011;118(5):831-839.

96. Singer MA, Awh CC, Sadda S, et al. HORIZON: an open-label extension trial of ranibizumab for choroidal neovascularization secondary to age-related macular degeneration. Ophthalmology. 2012;119(6):1175-1183. 
97. Silva R, Axer-Siegel R, Eldem B, et al; SECURE Study Group. The SECURE study: long-term safety of ranibizumab $0.5 \mathrm{mg}$ in neovascular age-related macular degeneration. Ophthalmology. 2013;120(1):130-139.

98. Fung AE, Lalwani GA, Rosenfeld PJ, et al. An optical coherence tomography-guided, variable dosing regimen with intravitreal ranibizumab (Lucentis) for neovascular age-related macular degeneration. Am J Ophthalmol. 2007;143(4):566-583.

99. Gupta OP, Shienbaum G, Patel AH, Fecarotta C, Kaiser RS, Regillo CD. A treat and extend regimen using ranibizumab for neovascular agerelated macular degeneration clinical and economic impact. Ophthalmology. 2010;117(11):2134-2140.

100. Lala C, Framme C, Wolf-Schnurrbusch UE, Wolf S. Three-year results of visual outcome with disease activity-guided ranibizumab algorithm for the treatment of exudative age-related macular degeneration. Acta Ophthalmol. 2013;91(6):526-530.

101. Martin DF, Maguire MG, Fine SL, et al. Ranibizumab and bevacizumab for treatment of neovascular age-related macular degeneration: two-year results. Ophthalmology. 2012;119(7):1388-1398.

102. Neri P, Mariotti C, Arapi I, Bambini E, Giovannini A. Anti vascular endothelial growth factor sequential therapy for neovascular agerelated macular degeneration: is this the new deal? Curr Med Res Opin. 2012;28(3):395-400.

103. Friberg TR, Tolentino M; LEVEL Study Group, Weber P, Patel S, Campbell S, Goldbaum M. Pegaptanib sodium as maintenance therapy in neovascular age-related macular degeneration: the LEVEL study. Br J Ophthalmol. 2010;94(12):1611-1617.

104. Inoue M, Arakawa A, Yamane S, Kadonosono K. Long-term outcome of intravitreal ranibizumab treatment, compared with photodynamic therapy, in patients with polypoidal choroidal vasculopathy. Eye (Lond). 2013;27(9):1013-1020; quiz 1021.

105. Schmidt-Erfurth U, Kaiser PK, Korobelnik JF, et al. Intravitreal aflibercept injection for neovascular age-related macular degeneration: ninety-six-week results of the VIEW studies. Ophthalmology. 2014;121(1):193-201.

106. Brown DM, Nguyen QD, Marcus DM, et al; RIDE and RISE Research Group. Long-term outcomes of ranibizumab therapy for diabetic macular edema: the 36-month results from two phase III trials: RISE and RIDE. Ophthalmology. 2013;120(10):2013-2022.

107. Do DV, Nguyen QD, Khwaja AA, et al; READ-2 Study Group. Ranibizumab for edema of the macula in diabetes study: 3-year outcomes and the need for prolonged frequent treatment. JAMA Ophthalmol. 2013;131(2):139-145.

108. Channa R, Sophie R, Khwaja AA, et al; READ-2 Study Group. Factors affecting visual outcomes in patients with diabetic macular edema treated with ranibizumab. Eye (Lond). 2014;28(3):269-278.

109. Campochiaro PA, Sophie R, Pearlman J, et al; RETAIN Study Group. Long-term outcomes in patients with retinal vein occlusion treated with ranibizumab: the RETAIN study. Ophthalmology. 2014;121(1): 209-219.

110. Korobelnik JF, Holz FG, Roider J, et al; GALILEO Study Group. Intravitreal aflibercept injection for macular edema resulting from central retinal vein occlusion: one-year results of the phase 3 GALILEO study. Ophthalmology. 2014;121(1):202-208.

111. Iacono P, Parodi MB, Papayannis A, Kontadakis S, Sheth S, Bandello F. Intravitreal bevacizumab therapy on an as-per-needed basis in subfoveal choroidal neovascularization secondary to pathological myopia: 2-year outcomes of a prospective case series. Retina. 2011;31(9): 1841-1847.

112. Lai TY, Luk FO, Lee GK, Lam DS. Long-term outcome of intravitreal anti-vascular endothelial growth factor therapy with bevacizumab or ranibizumab as primary treatment for subfoveal myopic choroidal neovascularization. Eye (Lond). 2012;26(7): 1004-1011.

113. Yang HS, Kim JG, Kim JT, Joe SG. Prognostic factors of eyes with naïve subfoveal myopic choroidal neovascularization after intravitreal bevacizumab. Am J Ophthalmol. 2013;156(6):1201-1210.e2.
114. Panos GD, Gatzioufas Z, Petropoulos IK, Dardabounis D, Thumann G, Hafezi F. Effect of ranibizumab on serous and vascular pigment epithelial detachments associated with exudative age-related macular degeneration. Drug Des Devel Ther. 2013;7:565-569.

115. Inoue M, Arakawa A, Yamane S, Kadonosono K. Variable response of vascularized pigment epithelial detachments to ranibizumab based on lesion subtypes, including polypoidal choroidal vasculopathy. Retina. 2013;33(5):990-997.

116. Erol MK, Ozdemir O, Coban DT, Ceran BB, Bulut M. Ranibizumab treatment for choroidal neovascularization secondary to causes other than age-related macular degeneration with good baseline visual acuity. Semin Ophthalmol. 2014;29(2):108-113.

117. Dardabounis D, Alvanos E, Gatzioufas Z, Panos GD. Intravitreal ranibizumab in choroidal neovascularisation due to multifocal choroiditis and panuveitis syndrome. BMJ Case Rep. 2013 Jul 17;2013. pii: bcr2013009572.

118. Petrou P, Georgalas I, Markomichelakis N, Vergados I, Gianakaki E, Rouvas A. Resolution of vitreomacular traction following intravitreal ranibizumab in cases of ocular toxoplasmosis with choroidal neovascularization. Ther Clin Risk Manag. 2013;9:391-394.

119. Castellanos MA, Schwartz S, Garcia-Aguirre G, Quiroz-Mercado H. Short-term outcome after intravitreal ranibizumab injections for the treatment of retinopathy of prematurity. Br J Ophthalmol. 2013;97(7): $816-819$

120. Ueta T, Yanagi Y, Tamaki Y, Yamaguchi T. Cerebrovascular accidents in ranibizumab. Ophthalmology. 2009;116(2):362.

121. Bressler NM, Boyer DS, Williams DF, et al. Cerebrovascular accidents in patients treated for choroidal neovascularization with ranibizumab in randomized controlled trials. Retina. 2012;32(9):1821-1828.

122. Kemp A, Preen DB, Morlet N, et al. Myocardial infarction after intravitreal vascular endothelial growth factor inhibitors: a whole population study. Retina. 2013;33(5):920-927.

123. Fong AH, Lai TY. Long-term effectiveness of ranibizumab for agerelated macular degeneration and diabetic macular edema. Clin Interv Aging. 2013;8:467-483.

124. Regillo CD, Brown DM, Abraham P, et al. Randomized, doublemasked, sham-controlled trial of ranibizumab for neovascular agerelated macular degeneration: PIER Study year 1. Am J Ophthalmol. 2008;145(2):239-248.

125. Holz FG, Amoaku W, Donate J, et al; SUSTAIN Study Group. Safety and efficacy of a flexible dosing regimen of ranibizumab in neovascular age-related macular degeneration: the SUSTAIN study. Ophthalmology. 2011;118(4):663-671.

126. Boyer DS, Heier JS, Brown DM, Francom SF, Ianchulev T, Rubio RG. A Phase IIIb study to evaluate the safety of ranibizumab in subjects with neovascular age-related macular degeneration. Ophthalmology. 2009;116(9):1731-1739.

127. Schmidt-Erfurth U, Lang GE, Holz FG, et al; RESTORE Extension Study Group. Three-year outcomes of individualized ranibizumab treatment in patients with diabetic macular edema: the RESTORE extension study. Ophthalmology. 2014;121(5):1045-1053.

128. Varma R, Bressler NM, Suñer I, et al; BRAVO and CRUISE Study Groups. Improved vision-related function after ranibizumab for macular edema after retinal vein occlusion: results from the BRAVO and CRUISE trials. Ophthalmology. 2012;119(10):2108-2118.

129. Finger RP, Wiedemann P, Blumhagen F, Pohl K, Holz FG. Treatment patterns, visual acuity and quality-of-life outcomes of the WAVE studya noninterventional study of ranibizumab treatment for neovascular age-related macular degeneration in Germany. Acta Ophthalmol. 2013;91(6):540-546.

130. Frennesson C, Nilsson UL, Peebo BB, Nilsson SE. Significant improvements in near vision, reading speed, central visual field and related quality of life after ranibizumab treatment of wet age-related macular degeneration. Acta Ophthalmol. 2010;88(4):420-425.

131. Rung L, Lövestam-Adrian M. Three-year follow-up of visual outcome and quality of life in patients with age-related macular degeneration. Clin Ophthalmol. 2013;7:395-401. 
132. Rakic JM, Leys A, Brié $\mathrm{H}$, et al. Real-world variability in ranibizumab treatment and associated clinical, quality of life, and safety outcomes over 24 months in patients with neovascular age-related macular degeneration: the HELIOS study. Clin Ophthalmol. 2013;7: $1849-1858$.

133. Holz FG, Bandello F, Gillies M, et al; LUMINOUS Steering Committee. Safety of ranibizumab in routine clinical practice: 1-year retrospective pooled analysis of four European neovascular AMD registries within the LUMINOUS programme. $\mathrm{Br} J$ Ophthalmol. 2013;97(9):1161-1167.
134. Ferrari G, Dastjerdi MH, Okanobo A, et al. Topical ranibizumab as a treatment of corneal neovascularization. Cornea. 2013; 32(7):992-997.

135. Heier JS, Brown DM, Chong V, et al; VIEW 1 and VIEW 2 Study Groups. Intravitreal aflibercept (VEGF trap-eye) in wet age-related macular degeneration. Ophthalmology. 2012;119(12):2537-2548.

136. Lalwani GA, Rosenfeld PJ, Fung AE, et al. A variable-dosing regimen with intravitreal ranibizumab for neovascular age-related macular degeneration: year 2 of the PrONTO Study. Am J Ophthalmol. 2009;148(1):43-58.e1.
Clinical Ophthalmology

\section{Publish your work in this journal}

Clinical Ophthalmology is an international, peer-reviewed journal covering all subspecialties within ophthalmology. Key topics include: Optometry; Visual science; Pharmacology and drug therapy in eye diseases; Basic Sciences; Primary and Secondary eye care; Patient Safety and Quality of Care Improvements. This journal is indexed on

\section{Dovepress}

PubMed Central and CAS, and is the official journal of The Society of Clinical Ophthalmology (SCO). The manuscript management system is completely online and includes a very quick and fair peer-review system, which is all easy to use. Visit http://www.dovepress.com/ testimonials.php to read real quotes from published authors. 